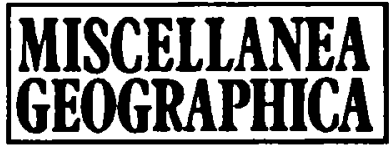

WARSZA WA 1996 VOI. 7

Dobiesław Jędrzejczyk

\title{
STUDIES ON HUMAN SETTLEMENT AND RELATED CONCEPTS BY WALENTY WINID (1894-1945)
}

Walenty Winid's works figure prominently among the works on geography of human settlement in Poland between the two world wars. Was a professor of the Economic Academy in Cracow. Died in the German extermination camp of Auschwitz. His generation of geographers, educated in the already independent country contributed many innovative solutions both in the field of theory and applied science.

In his research on urban network three major areas can be distinguished: empirical studies on settlement processes in Pomerania and on the Baltic Coast, theoretical studies on the functions of towns and measurement of settlement processes, and finally - the studies on the town itself - its spacial, social and economic structures as well as its links with the hinterland.

Already his first works were devoted to the economic role of different towns, Gdańsk above all (Winid 1925, a, b). For centuries it had dominated not only over the Baltic Sea, but also over the North Sea. It was only in the 18th century when Königsberg took the lead, in spite of the fact that its location was much less favourable both in geographical and economic terms. That change resulted mainly from the administrative and political decisions of the authorities of Prussia whose consistent policy reduced the role of Gdańsk by cutting its links with the country's natural hinterland the historic Polish lands.

In his essay W. Winid (1939) discussed the social and economic role of Gdańsk, which on the grounds of the Versailles Treaty was included into the Polish customs area. The essay was based on his paper Poland's maritime results as regards economics - A study of the importance of sea and the role of man in it presented in 1938 at the international geographical congress in Amsterdam. Polish seaports were proved by him to have played an important role in the reconstruction of the national economy of independent Poland by linking the country to nearly every part of the world. W. Winid questioned the thesis put forward by E. Neerf, the then assistant professor at the Technical University of Gdansk that claimed that only western part of the country i.e., the part of the partitioned Poland 
ruled by Prussia, was serviced by the Polish ports. The differences in turnovers with the ports between particular regions were not significant. Thus, the thesis, repeatedly quoted by German geographers, that Gdańsk maintained economic links only with the German Reich, was abolished.

The main focus, however, of Walenty Winid's research was on urbanization and measurement of urbanization processes. He developed interest in those topics during his stays in the United States and the United Kingdom where urbanization proceded much faster than anywhere in Central and Eastern Europe.

The ratio of urban population to population total or the ratio of urban population to area did not-according to W. Winid (1933) constitute adequate measures of urbanization or settlement as the concentrations of urban population in geographical space are like islands "surrounded by the rural landscape".

W. Winid, just as Christaller (1933), considered the town to be the central point of a well-delineated market area. In America its shape was square, whereas in Europe - hexagonal due to differences in the settlement processes in the two continents.

The distance between particular settlements is an important economic and social indicator. W. Winid (1933, p. 159) suggested that the avarage distance between different settlements should be measured by the square root of commercial area ${ }^{1}$.

Another W. Winid's important research contribution was to the study of functional structure and economic characteristics of urban settlements. His monograph of the United States of America published in 1937 was an early attempt at a functional classification of towns in the world literature. The "importance" of a town was defined on the basis of occupational structure of urban population, including the three main economic sectors: industry, transportation and services. Eight types of towns were distinguished in the USA according to the prevalence of particular kind(s) of economic activity: industry, transportation, transportation-and-industry, industry-and-transportation, services, services-and-transportation-and-industry, services-and-industry, industry-and-services. As some contemporary geographers have shown, e.g. K. Dziewoński (1910-1984) and M. Jerczyński, those types of cities can be identified in almost every form of the settlement process.

In his work on the United States, W. Winid discussed the rise of large urban agglomerations. In that country suburban settlements were typically formed around big cities and developed strong economic and social links with the city centres. That is how a new form of settlement, an "urban constellation" - as he called it - came into being.

\footnotetext{
${ }^{1}$ See in the same issue: J. Winidowa - "The method of distances and percentage shares of Walenty Winid. Application to the towns of Bangladesh".
} 
The rise of an urban agglomeration does not depend, however, on the size of a city, but on its economic characteristics, i.e., on the functions of the towns generally centrally located in the settlement system. Those towns were called by W. Winid "mother towns", whereas the towns around them - "associated towns” or "satellite towns”. Associated towns, as a rule came into being as industrial areas or residential districts, always tightly linked to the central town.

Apart from his research on agglomerations W. Winid studied morphology of towns, an excellent case study being his work on Chicago. W. Winid (1930) studied Chicago mainly as a particular social entity where geographical space is closely combined with the social and economic activity of a man. Chicago can be regarded as a typical great American city; its fast growth began as late as in the 19th century, and it had highly diversified social structure.

In his studies on human settlement, W. Winid (1937, p.17) also examined the links between the town and the country, regarding both of them as necessary elements of geographical landscape: "countryside is always natural, whereas an urban landscape is always man-made". They are also destined to play different social and economic roles, but in the real life they always come together.

The town cannot be self-sufficient not only because it needs agricultural products, but also rural labour force. Moreover - in W. Winid's opinion the country cannot be independent of the town. The greater the intensity of the rural economy, the further the country is from its autarchical model. This is because the improved tools and work techniques in the rural areas stimulate the consumption of goods and services produced in the town.

Already in the $1930 \mathrm{~s} \mathrm{W.} \mathrm{Winid,} \mathrm{while} \mathrm{analysing} \mathrm{settlement} \mathrm{process}$ noticed certain phenomena currently identified with urbanization. $\mathrm{He}$ pointed out that the impact of the town on the country was much stronger than social and economic system would to imply. That impact can be found in different areas: education, technology, town planning, politics.

W. Winid's writings on geography of human settlement rank among the best in the field, both in Poland and in the world geographical literature. Many of this works still inspire researchers to study settlement systems.

W. Winid studied towns not only within the context of natural environment, following the pattern set by F. Ratzel, but he also analysed the town functions on which growth of their economic potential depends, as well as the zones of their influence. His studies on towns development were given abroad social and economic setting and showed how large economic complexes, i.e. urban agglomerations came into being. A town itself - so characteristic of the 20th century civilization $W$. Winid viewed as a distinct social entity. This earned him the reputation of a pioneer of functional approach and "human ecology" in geography of settlement. 


\section{REFERENCES}

Christ all er W., 1933, Die zentrallen Orte in Süddeutschland. Jena, G. Fischer.

Winid W., 1925a, Gdańsk a Kanal Bydgoski (Gdańsk and the Bydgoszcz Canal), Strażica Zachodnia, no 1-3, 81-101.

Winid W., 1925b, Rozwój gospodarczy Gdańska a portów niemieckich (Economic development of Gdańsk and German ports), Ruch Prawniczy, Ekonomiczny i Socjologiczny, vol. 3, 695-705.

Winid W. 1930, Chicago. Amerykańskie miasto-olbrzym (Chicago. An American giant city), Przeglad Geograficzny, vol. X, 145-186.

Winid W., 1933, Sposoby przedstawienia umiastowienia (Means of presenting the urbanized area). Zbornik radova 11 Kongresa Slovenskich Geografia i Etnografa u Kralievini Jugoslavji 1930, Belgrad: Pripremin Odbor 111 K.S.G.E., 158-162.

Winid W., 1937, Miasto i wieś w krajobrazie geograficznym i ich rola w życiu gospodarczym i społecznym, (Town and country in geographical landscape and their role in economic and social life). Czasopismo Geograficzne, vol. VX, issue 4-18.

Wi n id W., 1937-1939, Stany Zjednoczone Ameryki Pótnocnej (The United States of America), Warszawa, Trzaska, Evert and Michalski.

Win id W., Polski handel zagraniczny a polskie porty. (The Polish foreign trade and Polish ports), Sprawy Morskie i Kolonialne, issue 1, 3-34. 